$327(470+571: 510)$

https://doi.org/10.18485/fb_nps.2018.ch8

\author{
Miroslav B. Mladenović \\ Redovni profesor, Univerzitet u Beogradu - \\ Fakultet bezbednosti
}

Jelena G. Ponomareva

Redovni profesor, Moskovski državni univerzitet za međunarodne odnose

(MGIMO)

\title{
Rusko-kineski odnosi u svetlu koncepcije „Pojas i put”
}

\begin{abstract}
Sažetak
Najveća i najmnogoljudnija zemlja na svetu imaju viševekovno iskustvo zajedničke granice, što skoro uvek podrazumeva brojne nesuglasice i sukobe. Iako ti problemi nisu mimoišli ni ove dve države, Rusija i Kina nikada nisu međusobno otvoreno ratovale. Takvo pozitivno nasleđe, uz zajednički interes za očuvanjem vlastitog suvereniteta, omogućava Rusiji i Kini raznovrsnu političku, ekonomsku, sledstveno tome - i vojnu saradnju. Aktuelna kineska ideja o „Novom putu svile” u dobroj meri može postati okvir za još bogatiju i sadržajniju bilateralnu, ali i regionalnu saradnju na nekim drugačijim osnovama. Iako shvata kinesku ideju kao težnju za ostvarivanjem liderske pozicije u svetu, Rusija prihvata saradnju u okviru tog projekta jer je zasnovan na principima mirnih i ravnopravnih odnosa, bez bilo kakvih mešanja u unutrašnje stvari država učesnica.

U radu se navode različiti argumenti kojima se dokazuje navedeno stanovište.
\end{abstract}

Ključne reči:

Rusija, Kina, „Jedan pojas - jedan put”, Evroazija, brze pruge

Odnosi Rusije i Kine oduvek su bili složeni i protkani manjom ili većom dozom nepoverenja, ali nikada nisu prerastali u otvorene vojne konfrontacije. Brojni nesporazumi oko utvrđivanja granica, osvajanje Sibira, širenje Carske Rusije do Sahalina, osnivanje Mongolije, građanski ratovi u obe zemlje, rivalstvo dve komunističke države, i drugi istorijski momenti, nisu 
rezultirali većim međudržavnim sukobima. Izuzetak su samo pogranični sukobi iz marta 1969. godine, koji su se odigrali na rečnim ostrvima Usure, posle kojih je ostalo nekoliko stotina poginulih vojnika s obe strane. Istaknuta istorijska činjenica deluje pomalo nestvarno, ako imamo u vidu buran razvoj jednog i drugog carstva i potonjih država, kao i brojne istorijske primere na drugim krajevima sveta, prepune sukobima i krvavim razračunavanjima u težnji za širenjem uticaja i uspostavljanje sopstvene dominacije. Nezavisno od razloga koji su uslovili takvo stanje stvari, izvesno je da odsustvo ratnog nasleđa omogućava savremenoj Rusiji i Kini da svoje odnose uređuju isključivo na pragmatičnim temeljima - u skladu sa vlastitim ekonomskim i drugim interesima koji funkcionišu izvan postulata političke ideologije ili vrednosnih pretpostavki kultura. ${ }^{1}$

Pragmatički osnov saradnje ukazuje na to da do nekakvog čvrstog saveza Kine i Rusije verovatno nikada neće doći. Međutim, s obzirom na ekonomske, demografske, prirodne i geografske potencijale, one će nastojati da tesno sarađuju i sačuvaju svoj suverenitet, odnosno mogućnost da, kao i do sada, samostalno odlučuju o sopstvenoj unutrašnjoj i spoljnoj politici. „I dok Kina, čini se, nezaustavljivo postaje ekonomski hegemon sveta, vojno revitalizovana Rusija postaje ranopravni politički akter u svetskim igrama moći. Na tom tragu valja sagledati današnju i buduću saradnju Kine i Rusije - „partnerstvo”, koje će svagda funkcionisati u balansiranju između racionalnog savezništva i tinjajućeg rivalstva. To nije zbližavanje na nekakvim „zajedničkim vrednostima”, već saradnja zasnovana isključivo na proračunatim uzajamnim ustupcima." ${ }^{2}$

Upravo u tom kontekstu i treba sagledavati kinesku strategijsku koncepciju „Jedan pojas - jedan put" u okviru koje se realizuju ideje "Novog puta svile” i "Morskog puta svile XXI veka” (vezanog za zemlje članice ASEAN-a).

Nema sumnje da će Narodna Republika Kina (NRK) dominirati u svetu tokom 21. veka. O tome govore brojni pokazatelji: brz ekonomski razvoj, ogromni strateški potencijali, veliko unutrašnje tržište, grandiozne investicije u infrastrukturu, obrazovanje, naučna istraživanja i dostignuća, kao i nezadrživo narastanje vojne moći. To praktično znači da, sa političkog i ekonomskog aspekta, polako ulazimo u vek Istočne i Jugoistočne Azije.

1 O glavnim istorijskim momentima odnosa Rusije i Kine, videti šire u: Miroslav Mladenović, Vladimir Cvetković, Savremeni rusko-kineski odnosi, Godišnjak Fakulteta bezbednosti, Univerzitet u Beogradu Fakultet bezbednosti, Beograd, 2015, str. 41-43.

2 Isto. 
Dok se po mnogo čemu može govoriti o „umoru” zapadne civilizacije, Kina se, očigledno, nalazi na uzlaznoj putanji svoje geostrategijske moći. Taj uspon ne može u potpunosti da se izrazi kvantitativno, ali i osnovni pokazatelji ekonomskog i opšteg progresa govore da se dešavaju radikalne promene na globalnoj slici sveta.

Ulazak Kine u zatvoreni krug „kosmičkih država”; stvaranje sopstvene Internet mreže na hijeroglifskoj osnovi, koja je praktično potpuno izdvojena od globalne mreže pod bezrezervnom dominacijom SAD; formiranje šangajske organizacije (ŠOS), 15. juna 2001. godine, kojom je praktično učvršćen „kondominijum” Rusije i NRK u postsovjetskoj Centralnoj Aziji; uvođenje, 1. marta 2006. godine, od strane Azijske banke, sopstvene valutne jedinice (Asian Currency Unit, ACU), uz učešće Japana ali sa vodećom ulogom juana; ozbiljna modernizacija oružanih snaga, itd., samo su neki od pokazatelja koji govore o nezaustavljivom prodoru "kineskog faktora” u svetu. ${ }^{3}$

Činjenica je da, uprkos intenzivnim nastojanjima, hegemonija SAD polako posustaje, dok se Kina približava liderskim pozicijama svetske politike, u okviru koje će sve otvorenije i odlučnije realizovati svoje interese. U okviru tog procesa, svakako se ne može očekivati dobrovoljno odustajanje SAD od stečene pozicije, pa je logično da će se konfliktni potencijal među ovim državama stalno povećavati. Čini se da je Fukujama malo poranio sa generalnim zaključkom o kraju istorije! Ispostavilo se da Hanktington ima više razloga za svoju tvrdnju o sukobu civilizacija.

Sagledavajući, u tom svetlu, situaciju izazvanu težnjom pojedinih subjekata međunarodnih odnosa da se zaustavi proces širenja NATO i nastojanjima da se podrži pluralizacija sveta kao prirodni proces, očekivati je da će se ekspertski pogledi sve više usmeravati ka ulozi Rusije u savremenom svetu i njenim odnosima sa SAD i NRK. Aktuelni spoljnopolitički, socijalno-ekonomski, pa i vojno-tehnički položaj Rusije, u poređenju sa SAD i NRK, znatno je skromniji, ali njen geoklimatski raspored, ogromni prirodni resursi, nuklearni štit, intelektualni potencijal građana i ogromno istorijsko iskustvo govore da će ova zemlja imati sve vidniju ulogu u međunarodnim odnosima. Poznato je da se geopolitička uloga Rusije tokom poslednjeg stoleća nekoliko puta radikalno menjala zajedno sa celokupnom „arhitekturom" sveta, ali je činjenica da je to država koja je uvek, na ovaj ili onaj način, bila respektivni subjekt međunarodnih odnosa.

Posle Prvog svetskog rata i velike Oktobarske revolucije, Sovjetska Rusija, a zatim i Sovjetski Savez, praktično su bili isključeni iz spiska „velikih država" kojima je, uz određena neslaganja, ipak pripadala Ruska Imperija.

3 M. Mladenović, E. Ponomareva, „Kina - Amerika - Rusija - globalni trougao 21. veka”, Sociološki pregled, Vol. 45, br. 4, Beograd, 2011, str. 459-476. 
Posle Drugog svetskog rata, SSSR je postao druga „superdržava” sveta. Rušenje SSSR u okviru "perestrojke” i degradacija Ruske Federacije tokom „tržišnih reformi" devedesetih godina prošlog veka ponovo su postavili državu u položaj geopolitičkog „preživljavanja”. Obnavljanje sistema državno-monopolskog kapitalizma posle dolaska na vlast Vladimira Putina vratilo je zemlju u red „velikih država”. Na taj način, mesto Rusije u svetskom sistemu je nestabilno, ali nikada nije značilo odlazak na periferiju svetske politike. $^{4}$

Ukupni potencijali koji stoje na raspolaganju Rusiji nesumnjivo obezbeđuju svrstavanje ove zemlje u sam vrh geopolitičke arhitekture sveta. Posebno $\mathrm{su}, \mathrm{u}$ aktuelnom trenutku, važne relacije odnosa u okviru "globalnog trougla": SAD, Kina i Rusija.

Odnos među „temenima trougla" nikada nije bio jednostavan i jednosmeran, i uvek je funkcionisao kao dinamička celina u kojoj se, približavanjem dva temena, treće uvek udaljava od njih. Generalno gledano, Kina predstavlja "prirodnijeg istorijskog” saveznika Rusije, s obzirom na to da kineski strateški interesi, za razliku od američkih, očigledno ne protivreče ruskim. NRK se ne meša u unutrašnje stvari Ruske Federacije, ne instalira svoju agenturu u rusku elitu, ne vrši ideološku obradu ruske omladine i ruskog javnog mnjenja. Na kraju, i Rusija i Kina su zainteresovane za strukturno jačanje države kao glavnog nosioca sopstvene civilizacije, $u$ to vreme kad SAD, na dugoročnom planu, vode politiku demontaže države (tuđe) kao elementa strukture budućeg sveta koji će biti formiran u okviru novog univerzalnog sistema pod američkim rukovodstvom. ${ }^{5}$

Događaji, izazvani protivrečnostima oko Ukrajine i Sirije, dobrim delom su uticali da se Rusija, možda i ne u tolikoj meri u kojoj bi želela, ${ }^{6}$

$4 \quad$ M. Mladenović, E. Ponomareva, „Kina - Amerika - Rusija - globalni trougao 21. veka”, Sociološki pregled, Vol. 45, br. 4, Beograd, 2011, str. 459-476.

5 Isto.

$6 \quad$ Shodno svojim spoljnopolitičkim koncepcijama, Rusija se ne orijentiše na strategijsko partnerstvo s NRK, koje bi podrazumevalo „zamrzavanje” odnosa s Vašingtonom. Ona bi želela da kompletna saradnja sa ovim centrima poprimi karakteristike dinamičke ravnoteže u okviru „globalnog trougla”, što bi dozvolilo Kremlju da, u određenoj meri, modeluje bilateralne odnose s Kinom i sa SAD, kao i da učestvuje u trostranim zajedničkim projektima koji bi imali odlučujući značaj za formiranje budućnosti čitave civilizacije. 
orijentiše prema NR Kini. U tom svetlu možemo posmatrati i odnos Moskve prema velikom kineskom projektu.

U svom govoru povodom promocije ideje "Jedan pojas - jedan put", na forumu u Pekingu, održanom 15. maja 2017. godine, kome je prisustvovao i ruski predsednik Putin, kineski šef države i partije, Si Đinping, izneo je osnovne postulate ovog projekta. Pre svega, to je put mira. Sve zemlje, duž „puta” uvažavaće suverena prava, teritorijalnu celokupnost, političko ustrojstvo i najvažnije interese svake učesnice. Pored toga, to je put ekonomskog razvoja jer je to univerzalni ključ za rešavanje svih problema. U okviru projekta proširiće se saradnja u oblasti industrijskog razvoja a finansiranje će teći bez barijera. Povezana infrastruktura jeste i biće osnova ekonomske saradnje.

Kineski predsednik je takođe istakao da je „Put svile” - put otvorenosti, jer samo otvorenost donosi progres. Budući da je trgovina glavni pokretač ekonomskog rasta, moraju se stvarati uslovi za uprošćavanje procesa trgovinske razmene i investicija. Kina se zalaže za otvorenu, inkluzivnu, balansiranu i, dobitnu za sve, ekonomsku globalizaciju.

Uporedo sa ovim, po rečima kineskog predsednika, „Pojas i put” je inovacioni projekat. U okviru njegove realizacije koristiće se nano tehnologija, veštačka inteligencija, kvantni kompjuteri i dr. Realizovaće se nova ideja „zelenog” razvoja vezana za očuvanje životne sredine, uz ogroman ekonomski napredak.

Pri svemu tome, „Novi put” treba da bude i kulturni put. Zemlje duž pojasa aktivno će razvijati i negovati i međusobnu kulturnu razmenu. ${ }^{7}$

Mnogovekovno iskustvo Kine uči da se plan, makar i strategijske važnosti, ne sme zasnivati na jednom uporištu. Zbog toga se, u okviru „Novog puta svile", predviđa objedinjavanje većine država Afrike i Evroazije u okviru tog ogromnog globalizacijskog projekta. Ideja je prilično jednostavna: železničke pruge idu iz Kine u sve krajeve sveta; duž tih puteva grade se fabrike, gradovi i logistički centri; izvlačeći korist iz trgovine s Kinom i međusobno, države koje su uključene u ovaj projekat se razvijaju, stabilizuju i postaju zavisne od kineske ekonomije; Kina postaje istinski lider planete.

U smislu sagledavanja globalističke sadržine „puta svile”, interesantno je pogledati varijante prostiranja trgovinskih puteva.

Put broj jedan - „Severni”, ide iz istočnog dela Kine kroz Mongoliju, sever Kine, Kazahstan i Rusiju i završava se u Poljskoj.

$7 \quad$ Iz govora kineskog predsednika Si Đinping na forumu održanom 15. maja 2017. godine u Pekingu; Sajt agencije Rusija danas; https://inosmi.ru/politic/20170517/239368854.html (posećeno 24.04.2018). 
Put broj dva - „Centralni”, prolazi kroz niz zemalja Srednje Azije i završava se na obalama Sirije. deša. ${ }^{8}$

Put broj 3 - „Južni”, ide u Pakistan, preko Mjanmara, Indije i Bangla-

Na prvi pogled, varijante ovih pravaca možda izgledaju pomalo čudno. Na primer, ako pogledamo put ka Evropi, na karti se uočava da bi najkraća i najbrža maršruta bila severno od Bajkalskog jezera, preko Hanti Mansijska i Moskve. Na taj način bi se izbeglo presecanje nekoliko granica, mimoišla Mongolija, Kazahstan i pribaltičke zemlje i znatno pojednostavio transport robe. Međutim, suština kineske ideje nije da se roba prebaci iz tačke „A" u tačku „B”, već da se maksimalno poveća kineski uticaj na što veći broj država. Projekat „Jedan pojas - jedan put” treba da poveže stotinak država.

Nova rešenja o globalnoj saradnji potpuno se uklapaju u tradicionalni pristup Kine rešavanju ekonomskih i političkih problema. Još je Den Sjaoping formulisao osnovni princip savremene kineske geopolitike - „vešto se širiti", i ostavio je zaveštanje svojim naslednicima da uvek čuvaju hladnu glavu, da ispoljavaju uzdržanost, da ne učestvuju u međunarodnim sporovima i da nikada ne deluju užurbano. U skladu sa tim, i sadašnje kinesko rukovodstvo, u okviru spoljne politike, deklariše duh nekonfliktnosti i nekonfrontacije, uzajamnog uvažavanja i obostrano korisne saradnje.

Naravno, kineska delatnost $u$ tom smeru ne realizuje se na pustom ostrvu. Tu je i konkurencija sa najvećim strategijskim partnerom - SAD. Upravo ta činjenica, kao i rečena strategija, uticaće da Kina primenjuje malo drugačija sredstva od američkih. Kina svakako neće osvajati prostranstva ognjem i dolarima i nametati obaveze slabijim državama da povećavaju penzijski staž i uzimaju uslovljavajuće kredite od MMF-a. Kina postepeno pozicionira sebe, ne kao demokratskog tiranina, već kao prvog među jednakima.

U okviru samog projekta mogu se uočiti četiri glavne orijentacije. Prva i najopštija - to je poziv za razvoj raznovrsnih trgovinsko-ekonomskih odnosa, preko liberalizacije trgovine i ekonomske integracije, do formiranja slobodne trgovine.

Druga se odnosi na izgradnju guste infrastrukturne mreže koja bi obezbedila "međuzavisnost" svih regiona ekonomskog pojasa.

Treća je - realizacija zajedničkih projekata uz učešće kineskog kapitala, energetske, transportne i informacione tehnologije. Kina više nije samo „svetska manufaktura”, već i najveći izvoznik kapitala sa specifičnim načinima realizacije, koji uključuju i kreditiranje sopstvenih tehnologija i radne snage.

8 Стратегия экономического развития „Один пояс - один путь”, Агенство РИА Новости; https://ria.ru/infografika/20170513/1494173299.html (posećeno 26.04.2018). 
Četvrta orijentacija se odnosi na nastojanje da se aktiviraju zapadni delovi Kine koji će, preko ovih projekata, dobiti izlaz u svet i razvijati krupne logističke baze.

Senzacionalna kineska koncepcija „Jedan pojas - jedan put”, kao što je rečeno, za osnovu ima saradnju velikog broja država: od Kine do Evrope, Azije i Afrike, ali na sasvim novim osnovama. Sama ideja je obelodanjena septembra 2013. godine, a, u skladu sa njom, kineski rukovodioci su već mnogo toga uradili na stvaranju njene ekonomske i političke osnove. Formiran je Fond Puta svile s kapitalom od 40.000.000.000 dolara; Kina je jedan od organizatora i najkrupniji partner Azijske banke za infrastrukturne investicije (100.000.000.000 dolara); potpisan je niz dokumenata i ugovora o zajedničkim projektima sa desetinama država koje su na „Putu svile”, itd. Po rečima kineskog predsednika, Kina će dopuniti resurse Fonda OUN za pomoć saradnji Jug - Jug do jedne milijarde dolara; primenjivaće se motivacija finansijskih institucija za vođenje međunarodnog biznisa u juanima (43.500.000.000 dolara); obezbediće se pomoć zemljama koje učestvuju u inicijativi „Pojas i put” u visini 8.700.000.000 dolara. Kineska banka za razvoj i Izvozno-uvozna banka, kao osnovne institucije za plasiranje kineskih sredstava za razvoj, razvile su specijalne mehanizme za kreditiranje u razmeri 36.200.000.000 i 18.800.000.000 dolara, za podršku saradnje u oblasti infrastrukturne izgradnje. ${ }^{9}$

Naravno, nerealno je očekivati da će svaka kineska ideja naići na potpun odziv zemalja na koje se odnosi. Ipak, treba imati u vidu da se projekat u celini prihvata pozitivno i da je naročito interesantan zemljama u razvoju, budući da je mnogo više u skladu sa njihovim realnim mogućnostima na savremenoj etapi razvoja.

Transportni koridori, koji se predviđaju u okviru koncepcije Novog puta svile, skratiće prevoz kineske robe do Evrope: od sadašnjih 45-60, na 10-13 dana. To može suštinski da pojednostavi transport i utiče na pojeftinjenje kineskih roba. Na taj način, dodatno će se učvrstiti položaj Kine na evropskim i azijskim tržištima i obezbediće se zauzimanje novih pozicija u Africi i na Bliskom istoku.

Iako još uvek u Kini postoje desetine miliona ljudi neuključenih u savremene ekonomske i tehnološke procese, njeni ljudski potencijali nisu beskonačni. Jedna od ideja novog projekta jeste da se na vreme obezbedi još veća potražnja za kineskim proizvodima, tehnologijom i investicijama van granica države.

9 Яна Лексютина, „Один пояс - один путь” - заявка Китая на мировое лидерство? Российский совет по меžдународным делам; http://russiancouncil.ru/analyticsand-comments/analytics/odin-poyas-odin-put-zayavka-kitaya-na-mirovoe-liderstvo/ (posećeno 23.04.2018). 
Posebnu oblast kineske ekonomije predstavlja izgradnja pruga, kako unutar tako i van granica države. Do kraja 2014. godine u Kini je izgrađeno $16.000 \mathrm{~km}$ brzih pruga (oko 60\% ove vrste koloseka u svetu). Do kraja 2020. godine planira se izgradnja brzih pruga u Kini u ukupnoj dužini $30.000 \mathrm{~km}$. U ovu granu uloženi su ogromni resursi koji obezbeđuju neverovatnu brzinu izgradnje tako da će Kina, uprkos veličini teritorije i broju stanovnika, relativno brzo biti zasićena ovim proizvodom. Ideja je da se kineska tehnologija, kapital, pa i radna snaga u oblasti izgradnje brzih pruga, širi i na druge delove sveta. U tom smislu, još 2014. godine, došlo je do objedinjavanja dva najkrupnija kineska proizvođača u oblasti brzinskih pruga (CNR i CSR).

U okviru opštih nastojanja, Kina je zainteresovana i za izgradnju železničkih pruga koje bi se integrisale sa unutarkineskom železničkom mrežom. U maju 2015. godine započeti su pregovori oko izgradnje brze pruge Moskva - Kazanj, dužine 770 km koja bi, u suštini, bila samo jedna etapa u izgradnji pruge Moskva - Peking. Brza pruga od Moskve do Kazanja skratiće vreme putovanja na ovoj destinaciji od dosadašnjih 14 na 3,5 časa.

Brza pruga Moskva - Peking treba da doprinese razvoju ne samo železničkih kompanija već država u celini. U dogledno vreme, pored ostalog, brze pruge treba da povećaju BDP u regionima kroz koje prolaze za 30-70\%. Dužina brze pruge kroz teritoriju Rusije iznosiće preko 2.300 kilometara i radiće se po etapama. Izgradnjom ove saobraćajnice, od evropske do istočne granice zemlje, moći će da se stigne za 65 časova. Danas najbrži voz iz Moskve do Vladivostoka ide sedam dana.

Nema sumnje da je za Rusiju važno učešće u projektima „Novog puta svile". To je šansa da ona učvrsti svoj položaj kao velika tranzitna zemlja i svojevrsni „evroazijski most” između Istoka i Zapada.

Učešće Rusije u projektu i porast tranzita kroz njenu teritoriju značajno će povećati angažovanost sredstava uloženih u transportnu infrastrukturu, čime će doprineti aktivnijem razvoju mnogih regiona azijskog dela zemlje.

U okviru geopolitičkih aranžmana, Rusija je generalno izuzetno zainteresovana za dobre odnose i saradnju s Kinom, ne samo usled aktuelnih, loših odnosa sa Zapadom. Zajednički, veliki projekti u suštini su najveća garancija za razvoj dugoročnog i stabilnog interesnog partnerstva.

Posebna zainteresovanost Rusije za saradnju sa Kinom tiče se pograničnih oblasti. Skoro da je nemoguć razvoj mnogih regiona Sibira i Dalekog istoka bez učešća velikog suseda.

Pored ekonomskih, postoje i značajni politički razlozi za učešće Rusije u projektu „Novi put svile”. I Kina i Rusija su zainteresovane za usposta-vljanje političke stabilnosti u zemljama Centralne Azije i Bliskog istoka, kao i za njihov ekonomski razvoj. Poseban problem predstavlja proizvodnja narkotika u Avganistanu i narko-trafiking vezan sa njom. Značajnu 
opasnost čine i dejstva fundamentalista i nekontrolisani tokovi izbeglica, proizašlih tokom brojnih oružanih dejstava. Obe države su na stanovištu da je osnova za političku stabilnost u ovim zemljama ubrzavanje njihovog ekonomskog razvoja i povećanje kvaliteta života u njima. Projekat „Novog puta svile" može, u tom smislu, da odigra izuzetno važnu ulogu.

Veoma bitan segment $\mathrm{u}$ okviru kineske inicijative svakako predstavlja svojevrsni rivalitet sa ruskim projektom „Evroazijskog ekonomskog saveza". Očekivati je da će se države Centralne Azije naći pred nekom vrstom izbora između ove dve mogućnosti. Objektivno, ruske šanse u tom procesu su manje tim više što Kina, u centralnoazijskim zemljama, već gradi infrastrukturne objekte, naučne, industrijske i agrarne parkove koji treba da postanu osnova za širenje ekonomske saradnje. Najbolja opcija za Rusiju bilo bi stapanje ova dva projekta na prostoru Centralne Azije. Kina je već diplomatski stavila do znanja Moskvi da su njene mogućnosti za stvaranje Evroazijskog saveza ograničene i da bi bilo najbolje da on postane deo megaprojekta "Novi put svile".

Rusiji svakako pogoduje nova forma međunarodne regionalizacije, koju plasira NR Kina. Umesto političkih saveza i nasilne „demokratizacije”, nude se transgranični komunikacijski koridori, u čijoj su osnovi transportno-logistički čvorovi i trgovinsko-proizvodne zone koje gradi novi geopolitički lider.

Ovakav pristup obezbeđuje odsustvo konfrontacije među državama kroz koje prolazi „ekonomski pojas svile”. Peking predlaže ekonomsku saradnju saglasno staroj istočnoj mudrosti po kojoj „Kad ide trgovina - topovi ćute”.

O tome da u kineskoj inicijativi „Pojas i put” Rusija zauzima posebno mesto može se zaključiti po činjenici da će Državni komitet za reforme i razvoj Kine formirati Kinesko-ruski investicioni fond za regionalnu saradnju i razvoj u visini od 100.000.000.000 juana (14.500.000.000 dolara). Sa svoje strane, ruski predsednik Putin, učestvujući na forumu u Pekingu, posvećenom ovom kineskom projektu, visoko je ocenio ovu kinesku inicijativu i izrazio spremnost Rusije za učešće $u$ njoj. ${ }^{10}$

Bez obzira na nesumnjivu i vidnu težnju NR Kine da, realizacijom projekta "Novi put svile", postane dominantan faktor u svetu, Rusiji takva težnja odgovara jer je zasnovana na sredstvima i principima koji su znatno prihvatljiviji

10 Яна Лексютина, „Один пояс - один путь” - заявка Китая на мировое лидерство? Российский совет по меžдународным делам; http://russiancouncil.ru/analyticsand-comments/analytics/odin-poyas-odin-put-zayavka-kitaya-na-mirovoe-liderstvo/ (posećeno 23.04.2018). 
od onih na kojima se do sada održavala piramida svetske hegemonije. Glavni među njima su: mogućnost očuvanja samostalnosti i viševektorne spoljne politike, beskonfliktnost u međunarodnim odnosima, realizacija državnih interesa ekonomskim, političkim i kulturnim sredstvima, poštovanje principa i pravila međunarodnog prava, nenametanje univerzalnih rešenja unutrašnjeg ustrojstva koja ne izviru iz tradicije, kulture, ekonomije i želja samih građana, itd. ${ }^{11}$

\section{LITERATURA}

1. Govor kineskog predsednika Si Đinpinga na forumu održanom 15. maja 2017. godine u Pekingu; Sajt agencije Rusija danas; https://inosmi.ru/politic/20170517/239368854.html

2. Яна Лексютина. „Один пояс - один путь” - заявка Китая на мировое лидерство? Российский совет по меžдународным делам; http://russiancouncil.ru/analytics-and-comments/analytics/odin-poyas-odin-put-zayavka-kitaya-na-mirovoe-liderstvo/

3. Miroslav Mladenović, Vladimir Cvetković. Savremeni rusko-kineski odnosi, Godišnjak Fakulteta bezbednosti, Univerzitet u Beogradu Fakultet bezbednosti, Beograd, 2015, str. 41-43.

4. Miroslav Mladenović, Jelena Ponomareva. „Kina - Amerika - Rusija - globalni trougao 21. veka", Sociološki pregled, Vol. 45, br. 4, Beograd, 2011, str. 459-476.

5. Мирослав Младеновић. „Современные российско-китайские отношения: взгляд из Сербии", стр. 33-39, излагање (штампано у целини), у: Развитие российско-китайских отношений: новая межуународная реальность, Часть 2, Издательство БГУ, Иркутск, 2016, стр. 33-39.

6. Miroslav Mladenović, Jelena Ponomareva. „'Meka moć' Rusije - kao uslov uspeha evroazijske integracije", Srpska politička misao, broj 1/2016, god. 23, Vol. 51, Beograd, str. 11-29.

7. Стратегия экономис̌еского развития „один пояс - один путь”, Агенство РИА Новости; https://ria.ru/infografika/20170513/1494173299.html

11 Мирослав Младеновић, „Современные российско-китайские отношения: взгляд из Сербии", (стр. 33-39), излагање (штампано у целини), у: Развитие российско-китайских отношений: новая межяунарояная реальность, Часть 2, Издательство БГУ, Иркутск, 2016, стр. 33-39. 